\title{
Amaranthus palmeri a New Invasive Weed in Spain with Herbicide Resistant Biotypes
}

\author{
Joel Torra ${ }^{1, *} \mathbb{C}^{\circ}$, Aritz Royo-Esnal ${ }^{1} \mathbb{C}$, Yolanda Romano ${ }^{2}$, María Dolores Osuna ${ }^{2}$, \\ Ramón G. León ${ }^{3}$ iD and Jordi Recasens ${ }^{1}$ (D) \\ 1 Departament d'Hortofructicultura, Botànica i Jardineria, Agrotecnio, Universitat de Lleida, \\ 25198 Lleida, Spain; aritz.royo@udl.cat (A.R.-E.); jordi.recasens@udl.cat (J.R.) \\ 2 Agrarian Research Center 'Finca La Orden' Valdesequera, 06187 Badajoz, Spain; yigui76@hotmail.com (Y.R.); \\ mdosuna@gmail.com (M.D.O.) \\ 3 Department of Crop and Soil Sciences, North Carolina State University, Raleigh, NC 27695-7620, USA; \\ rleon@ncsu.edu \\ * Correspondence: joel.torra@udl.cat; Tel.: +34-973-702318
}

Received: 12 June 2020; Accepted: 9 July 2020; Published: 10 July 2020

check for updates

\begin{abstract}
Amaranthus palmeri is the most prominent invasive weed in agricultural land from North America, partly due to its propensity to evolve resistance to multiple herbicide sites of action. In the last two decades, reports of this species have increased throughout the American continent and occasionally in other continents. In 2007, A. palmeri populations were found in three localities in northeastern Spain, and they are still present today. To determine whether these three populations resulted from a common or independent introduction events-and when and from where they could have occurred-research was carried out aiming to characterize the resistance profile and mechanisms to 5-enolpyruvylshikimate-3-phosphate synthase-and acetolactate synthase (ALS)-inhibiting herbicides and to analyze the relationship between these three populations using inter simple sequence repeat DNA fingerprinting. Dose-response trials confirmed that the three populations were susceptible to glyphosate but resistant to nicosulfuron-methyl. Resistance to ALS inhibitors was due to several amino acid substitutions in positions Pro197, Trp574 and Ser653. Moreover, the substitutions Ser653Ile and Pro197Thr are described for the first time in this species. At field-labeled rates, all populations were fully controlled with alternative herbicides with other sites of action. Amaranthus palmeri individuals were clustered in three groups based on unweighted pair group method with arithmetic mean analysis, which corresponded to the three sampled populations, with a $67 \%$ of genetic relationship among them. Considering this high genetic variability and the different positions and amino acid substations found between populations, it was hypothesized that different colonization events occurred from the American continent probably prior to the introduction of glyphosate resistant crops. Prevention from new introductions is warranted because new herbicide resistance traits could arrive, complicating the management of this invasive weed species, while managing or eradicating the already established populations.
\end{abstract}

Keywords: alien plant; ALS inhibitors; dendrogram; glyphosate; inter simple sequence repeat (ISSR) DNA fingerprinting; maize; nicosulfuron-methyl; target-site resistance

\section{Introduction}

Invasive plant species are a major cause of crop loss and can adversely affect food security [1]. In the United States, crop losses from invasive weeds have been estimated at about US $\$ 27,000$ million per year [2]. The threat from plant invasive species arriving to countries in which they were previously absent is expected to increase with globalization and connectedness via world trade. 
Quantifying this threat and developing effective security policies requires an understanding of potential sources, likelihood of arrival, likelihood of establishment upon arrival, and an estimation of their potential impact on the existing ecological and production systems [1]. Agricultural landscapes, characterized by human disturbance, are particularly associated with the spread of invasive exotic plants [3]. Several attributes confer plant species the capacity to become invasive weeds in agricultural systems, including seed dispersal strategy, high growth rate, reproduction capacity, genetic variability, stress tolerance or photosynthetic efficiency [4].

Amaranthus palmeri S. Watson is a diploid plant native to the Sonoran Desert in the southwestern North America [5]. Nowadays, it is present across a great part of North America, and has invaded Brazil and Argentina in South America, where it causes significant yield losses in cotton (Gossypium hirsutum L.), soybean (Glycine max (L.) Merr.) and maize (Zea mays L.). Amaranthus palmeri is a wind-pollinated dioecious weed, allowing for gene exchange contributing to genetic variability, and is considered to be a factor enhancing herbicide resistance evolution [6]. In its native desert habitat, this C4 species has high stress tolerance, such as intense heat and low unpredictable rainfall. Studies showed that female plants are prolific seed producers, with an average ranging from 200,000 to 600,000 seeds per plant when growing without competition [7] and exceptionally as high as 1,800,000 seeds [8]. Seed bank persistence has not been properly studied, but it is known that up to $22 \%$ of deep buried $(40 \mathrm{~cm})$ seeds stayed viable for at least three years [9]. The small seeds are predominantly gravity-dispersed but can also be spread by water flow and irrigation as well as by birds and mammals [10].

Unfortunately, A. palmeri is already present in Southern and Central Europe and Mediterranean coastal and insular territories such as Cyprus, Israel and Portugal (Madeira). For this reason, in 2014, this species was included in the EPPO alert list due to the potential risk it represents to agricultural systems in Europe [11]. Amaratnhus palmeri is suspected to have entered Belgium as a contaminant of grain and to have entered the UK as a contaminant of oil seed rape [11]. In Spain, A. palmeri was recorded as a casual finding in Manlleu (Barcelona) in 1877 and in the port of Seville in 1979 [12]. Later findings were recorded in Palos de la Frontera (Huelva) [13], but after that, there were no further reports. However, in 2007, populations of this species were found in two sites in the province of Lleida (Catalonia, northeast of Spain) [14], which became the discovery of the weed in an agricultural field margin (maize) and its initial process of colonization and on roadsides [15]. In 2010, another A. palmeri population was observed and recorded in Binéfar, in the nearby province of Huesca and only about $50 \mathrm{~km}$ away from the previous two sites in Lleida. These three populations have encountered a hospitable environment compatible with this species growth requirements or they are quickly naturalizing, which is evident in their ability to exhibit vigorous seedling emergence, rapid growth, successful and abundant fecundity and the formation of stable and persistent seed banks across years [16].

As previously stated, the propensity of $A$. palmeri to develop multiple herbicide resistance reflects its outstanding genetic variability and adaptiveness [10]. To date, since herbicide resistant (R) populations are found both in North and South America, the potential resistance profile and mechanisms present of invading populations across the world may help indicate the source of origin and potentially provide insights into the history of the invasion. Although non-target-site mechanisms of resistance to glyphosate have been recently described in A. palmeri [17], the most common resistance mechanism is the amplification of the 5-enolpyruvylshikimate-3-phosphate synthase (EPSPS) gene [18], despite the fact that the point mutation Pro106Ser has also been found in some Mexican populations [19]. Glyphosate R populations are spread across all the United States, where they have been reported in at least 30 states, and also more recently in Argentina [20]. For acetolactate synthase (ALS)-inhibiting herbicides, resistance was already reported in the 1990s [21]. Nowadays, ALS R populations are reported in Argentina [22], Brazil (multiple resistance including to glyphosate), Israel, and are common in the United States [20]. In the latter country, populations only R to ALS are reported in eight states, while multiple $\mathrm{R}$ populations including glyphosate in eleven states. Predominant resistance mechanisms to ALS-inhibiting herbicides are target-site based with missense point mutations. To date, 
there are reported six codons with mutations in the ALS gene [23]. Finally, non-target site resistance mechanisms to ALS inhibitors have also recently been identified [24].

Several important questions arise as the result of $A$. palmeri recent introduction and invasion of habitats in NE Spain, which will be addressed in this research: (1) Were the three identified populations originated from a unique initial spread point or did the colonization process take place separately? (2) Do these populations carry herbicide resistance alleles? and (3) When and from where did the first colonization process take place? These and other questions define an interesting scenario for A. palmeri to understand if an initial invasion process took place in summer crops in NE Spain and the potential necessity of developing a pest risk assessment for this species.

\section{Materials and Methods}

\subsection{Plant Material}

In autumn 2016 mature seeds were collected from three A. palmeri populations located in north eastern Spain (Lleida, Menàrguens and Binéfar). Since 2007, these populations were monitored and positively identified every year (until 2019) on roadsides and maize field edges in Menàrguens in Lleida province $\left(41^{\circ} 43^{\prime} \mathrm{N} 0^{\circ} 45^{\prime} \mathrm{E}\right)$, in industrial areas nearby the city of Lleida $\left(41^{\circ} 37^{\prime} \mathrm{N} 0^{\circ} 39^{\prime} \mathrm{E}\right)$, both in Catalonia and road sides of Binéfar (Huesca) in Aragon region $\left(41^{\circ} 49^{\prime} \mathrm{N} 0^{\circ} 18^{\prime} \mathrm{E}\right)$. Seed from an A. palmeri population was collected in autumn 2014 from Bulloch County, Georgia, US $\left(81^{\circ} 40^{\prime} \mathrm{N} 32^{\circ} 19^{\prime} \mathrm{E}\right)$ from a vegetable organic farm with no history of herbicide use in more than twenty years and used as the susceptible (S) standard [25] for the dose-response experiments described below. Seeds were collected separately from at least twenty different mature plants (without herbicide injury) randomly selected and brought to the laboratory; there they were threshed and cleaned and left to dry in paper bags at room temperature until experiments started. Seeds from the $S$ population were collected, dried, and kept under cold storage $\left(4^{\circ} \mathrm{C}\right)$ until used [25].

\subsection{Dose-Response Trials}

Dose-response experiments were conducted in 2018 using the three Spanish A. palmeri populations and the $S$ standard population from US. Seeds were sown in aluminum trays with peat. Trays were placed in a growth chamber at $15 / 25^{\circ} \mathrm{C}$ day/night and a $12 / 12 \mathrm{~h}$ photoperiod under $350-\mu \mathrm{mol} \mathrm{m} \mathrm{m}^{-2} \mathrm{~s}^{-1}$ photosynthetic photon-flux density. After $14 \mathrm{~d}$, seedlings were transplanted to 8 by 8 by $8 \mathrm{~cm}$ plastic pots filled with a mixture of silty loam soil, sand and peat (1.3:1:1 by volume). Three seedlings were transplanted per pot and later thinned to two. Pots were brought to a greenhouse at the University of Lleida, Spain $\left(41.629^{\circ} \mathrm{N}, 0.598^{\circ} \mathrm{E}\right)$. At the 5- to 6-leaf stage ( 5 to $\left.6 \mathrm{~cm}\right)$, the ALS inhibitor nicosulfuron-methyl and the EPSPS inhibitor glyphosate were applied separately to different pots at the rates $0,7.5,15,30,60,120,240 \mathrm{~g}$ a.i. $\mathrm{ha}^{-1}$ and $0,75,150,300,600$ and $1200 \mathrm{~g}$ a.i. ha ${ }^{-1}$, respectively. A total of four replicates (pots) were included for each dose in a completely randomized design, and the experiment was repeated. Herbicides were applied using a precision bench sprayer delivering $200 \mathrm{~L} \mathrm{ha}^{-1}$ at a pressure of $215 \mathrm{kPa}$. Pots were placed in the greenhouse and were regularly watered. At 4 weeks after treatment, weed control efficacy in terms of mortality (\%) from each dose was evaluated for each pot and aboveground dry weight evaluated after $24 \mathrm{~h}$ at $72{ }^{\circ} \mathrm{C}$ in an oven. The data were expressed as a percentage of dry weight reduction compared to the untreated control. Plants without green tissues were classified as dead.

\subsection{Alternative Herbicides}

As described above, several alternative herbicides were applied at field recommended rates to the three Spanish A. palmeri populations to assess their sensitivity to different chemical options available in the market for weed control in maize crop. Additionally, thifensulfuron-methyl (group B, according to HRAC, Herbicide Resistance Action Committee) was also applied at field rate to study potential cross-resistance to other sulfonylurea ALS inhibitors. The herbicides S-metolachlor (group K3, 
S-metolachlor 96\%, Dual Gold, Syngenta) and isoxaflutole (group F2, isoxaflutole 24\%, Spade Flexx, Bayer CropScience) were applied preemergence (BBCH 00). Dicamba (group O, dicamba 48\%, Banvel-D, Syngenta), sulcotrione (group F2, sulcotrione 30\%, Decano, Ascenza Agro), mesotrione (group F2, mesotrione 10\%, Callisto 100, Syngenta) and thifensulfuron (thifensulfuron 50\%, Harmony 50, FMC Agricultural Solutions) were applied postemergence as described for the dose-response experiments. Five seeds were sown for the preemergence treatments, which all germinated after in the corresponding untreated controls. A total of four replicates (pots) were included for each herbicide in a completely randomized design. The experiment was not repeated. Weed control efficacy in terms of mortality (\%) was assessed 4 weeks after treatments. Plants were scored as dead when were all necrotic or alive if they were undamaged or clearly still growing with green parts.

\subsection{ALS Gene Sequencing}

DNA from the leaf fragment of new grown plants was extracted using the Speedtools Plant DNA Extraction Kit (Biotools B\&M Labs S.A., Valle de Tobalina, Madrid, Spain) and the DNA sample concentration was measured in a NanoDrop Thermo Scientific spectrophotometer (Thermo Fisher, Nano Drop Products, Wilmington, DE, USA). Each DNA sample was diluted to a final concentration of $10 \mathrm{ng} \mu \mathrm{L}^{-1}$, which was immediately used for the polymerase chain reaction (PCR) test or stored at $-20{ }^{\circ} \mathrm{C}$ until use. All mutations conferring ALS resistance in A. palmeri in positions Gly654, Ser653, Trp574, Ala205, Pro197 and Ala122 of CAD and BE domains. Mutations were found in positions Ser653, Trp574 and Pro197. [26] were analyzed for all the samples. Fragments of the ALS gene that included the regions of those codons were amplified using two pairs of primers (Table 1 ) designed from the ALS sequence accession number KT833339 of the Genbank (A. palmeri) using the PRIMER 3 PLUS software. The mixture of each reaction contained: $10 \mathrm{ng}$ of genomic DNA, $3 \mu \mathrm{L}$ of reaction buffer (10x), $2.4 \mu \mathrm{L}$ dNTP $(2.5 \mathrm{mM}), 1.125 \mu \mathrm{L}$ of primer $\left(10-p m o l ~ \mu \mathrm{L}^{-1}\right)$ and $0.3 \mu \mathrm{L}$ of Taq polymerase (5 units $\mu \mathrm{L}^{-1}$ ) in a final volume final of $30 \mu \mathrm{L}$. The amplification was done with a program of 1 cycle of $5 \mathrm{~min}$ at $94^{\circ} \mathrm{C}, 36$ cycles of $40 \mathrm{~s}$ at $94^{\circ} \mathrm{C}, 4 \mathrm{~s}$ at $57^{\circ} \mathrm{C}$ and $50 \mathrm{~s}$ and $8 \mathrm{~min}$ at $72{ }^{\circ} \mathrm{C}$ and a final cycle of $8 \mathrm{~min}$ at $72{ }^{\circ} \mathrm{C}$. The separation of the amplified DNA fragments by PCR was done by horizontal electrophoresis in agarose gel 1.3\% (w/v) and they were stained with Red Safe 20000X (Intron) and images recorded with gel photography. Amplified DNA fragments were purified using the Speed tools PCR clean-up kit (Biotools, B\&M Labs, Madrid, Spain). Sequencing of the purified amplified DNA fragments was carried out by the STAB (Service of Applied Techniques to Bioscience) at the University of Extremadura (Spain).

Table 1. Primers pairs (forward; reverse) used for the PCR amplification of the domains CAD and BE of the acetolactate synthase $(A L S)$ gene.

\begin{tabular}{ll}
\hline \multicolumn{1}{c}{ Name } & \multicolumn{1}{c}{ Sequence } \\
\hline Ama BE 2 Forward & 5'-TGCTATTGGAGCTGCTGTTG-3' \\
Ama BE 1 Reverse & 5'-CCTTCTTCCATCACCCTCTG-3' \\
Ama CAD 1 Forward & 5'-CGCCCTCTTCAAATCTCATC-3' \\
Ama CAD Reverse & 5'-CAATCAAAACAGGTCCAGGTC-3' \\
\hline
\end{tabular}

\subsection{ISSR DNA Fingerprinting}

Seeds from individual plants were germinated in the greenhouse to generate 20 plants of each Spanish A. palmeri population. The DNA material from each plant was extracted from young leaves using the commercial kit Speedtools Plant DNA Extraction Kit (Biotools B\&M Labs S.A., Valle de Tobalina, Madrid, Spain). For the analyses with the molecular markers, seven primers of the (inter simple sequence repeat) ISSR type were used (Table 2), which were chosen among a group of 18 primers (University of British Columbia, primer set $n^{\circ}$ 9, Vancouver, Canada) to present polymorphisms and a clear and reproducible amplification pattern. The mixture of each reaction contained: $10 \mathrm{ng}$ of genomic DNA, $1.5 \mu \mathrm{L}$ of reaction buffer $10 \mathrm{x}, 0.6 \mu \mathrm{L} \mathrm{dNTP}, 0.2 \mu \mathrm{L}$ of primer and 
$0.3 \mu \mathrm{L}$ of Taq polymerase ( 5 units $\mu \mathrm{L}^{-1}$, Sigma) in a final volume final of $15 \mu \mathrm{L}$. The amplification was done with a program of 1 cycle of $5 \mathrm{~min}$ at $94{ }^{\circ} \mathrm{C}, 40$ cycles of $30 \mathrm{~s}$ and $94{ }^{\circ} \mathrm{C}, 45 \mathrm{~s}$ at $52{ }^{\circ} \mathrm{C}$ and $2 \mathrm{~min}$ at $72{ }^{\circ} \mathrm{C}$ and a final cycle of $7 \mathrm{~min}$ at $72{ }^{\circ} \mathrm{C}$. The separation of the amplified DNA fragments by PCR was done by horizontal electrophoresis in agarose gel $1 \%(w / v)$ and they were stained with red safe 20000X (intron).

Table 2. Sequences of the inter simple sequence repeat (ISSR) primers used in this study.

\begin{tabular}{ll}
\hline \multicolumn{1}{c}{ Name } & \multicolumn{1}{c}{ Sequence } \\
\hline ISSR 808 & 5'-AGAGAGAGAGAGAGAGC-3' $^{\prime}$ \\
ISSR 889 8 5'-DBDACACACACACACAC-3' \\
ISSR 890 & 5'-VHVGTGTGTGTGTGTGT-3' \\
ISSR 857 & 5'-ACACACACACACACACYG-3' \\
ISSR 836 & 5'-AGAGAGAGAGAGAGAGYA-3' \\
ISSR 827 & 5'-ACACACACACACACACG-3' \\
ISSR 880 & 5'-GGAGAGGAGAGGAGA-3' \\
ISSR 810 & 5'-GAGAGAGAGAGAGAGAT-3' \\
\hline
\end{tabular}

\subsection{Data Analysis}

Data from dose-response experiments were analyzed using a nonlinear regression model (1) with SigmaPlot 11.0 (Systat Software, Inc., San Jose, CA, USA). The herbicide rate required for 50\% growth reduction of plants $\left(\mathrm{GR}_{50}\right)$ or $50 \%$ of plant mortality $\left(\mathrm{LD}_{50}\right)$ was calculated with the use of a four parameter logistic curve:

$$
y=c+\frac{(d-c)}{1+\operatorname{EXP}[b(\log (x)-\log (\text { GR50 or LD50 })]}
$$

where $c=$ the lower limit adjusted to $0, d=$ the upper limit adjusted to 100 and $b=$ the slope at the $\mathrm{LD}_{50}$ or $\mathrm{GR}_{50}$. In this regression equation, the herbicide rate ( $\mathrm{g}$ a.i. ha ${ }^{-1}$ ) was the independent variable $(x)$ and the plants' dry weight expressed as percentage of the untreated control or mortality were the dependent variables $(y)$. The resistance index $(R I)$ was computed as $G_{50}(R) / G R_{50}(S)$ or $\mathrm{LD}_{50}(\mathrm{R}) / \mathrm{LD}_{50}(\mathrm{~S})$.

Weed control efficacies (\% of mortality) of alternative herbicides experiment were analyzed with one-way ANOVA considering population as factor for each herbicide tested.

The results of sequencing were visualized using CHROMAS 2.6.6 software (Technelysium Pty Ltd., South Brisbane, Australia). Subsequently, these sequences were aligned using the CLUSTAL OMEGA software (EMBL-EBI, Hinxton, UK). Heterozygous base pairs were identified in the sequence trace files by manual inspection.

Genetic relationships among the studied populations were assessed using the unbiased genetic identity coefficient (I) of Nei [27], which ranges from I $=0.0$ for populations with no genetic similarity to $\mathrm{I}=1.0$ for populations that are genetically identical. The phylogenetic analysis was based on the unweighted pair group method with arithmetic mean (UPGMA) for the DNA fingerprint data using the software Numeric Taxonomy System (NTSYS)-pc 2.2 (Exeter Software, Exeter, UK) [28].

\section{Results}

\subsection{Dose-Response Trials}

The populations Binéfar, Menàrguens and Lleida were 6.8-, 4.0- and 11.0-fold more $\mathrm{R}$ to nicosulfuron-methyl than $S$ plants in terms of mortality (Table 3, Figure 1). Only the S standard population was fully controlled at the field dose. The $\mathrm{LD}_{50}$ values ranged from 19 for the $\mathrm{S}$ population to $209 \mathrm{~g}$ a.i. ha ${ }^{-1}$ for the most $\mathrm{R}$ one. Considering the dry weight reduction (\%) compared to untreated 
controls, RI were 4.8, 3.7 and 12.1, respectively, for the same populations, with $\mathrm{GR}_{50}$ values between 22 (S population) and $271 \mathrm{~g}$ a.i. $\mathrm{ha}^{-1}$.

Table 3. Estimated slopes $(b)$, plant mortality $\left(\mathrm{LD}_{50}\right)$ and growth reduction of plants $\left(\mathrm{GR}_{50}\right)$, $p$-values (level of significance of curves fitting) and resistance index (RI) values for mortality (\%) and dry weight reduction (\%) to nicosulfuron-methyl and glyphosate for several Amaranthus palmeri populations in 2018: three from Spain and one susceptible (S) standard from US.

\begin{tabular}{|c|c|c|c|c|c|c|c|c|c|c|}
\hline \multirow[b]{2}{*}{ Herbicide } & \multirow[b]{2}{*}{ Field Dose } & \multirow[b]{2}{*}{ Population } & \multicolumn{4}{|c|}{ Mortality (\%) } & \multicolumn{4}{|c|}{ Dry Weight Reduction (\%) } \\
\hline & & & $b$ & $\begin{array}{c}\mathrm{LD}_{50} \\
\text { (g a.i. } \cdot \mathbf{h a}^{-1} \text { ) }\end{array}$ & RI & $p$-Value & $b$ & $\begin{array}{c}\mathrm{GR}_{50} \\
\text { (g a.i.'ha-1) }\end{array}$ & RI & $p$-Value \\
\hline \multirow{4}{*}{ Nicosulfuron-methyl } & \multirow{4}{*}{$60 \mathrm{~g}$ a.i.ha ${ }^{-1}$} & Susceptible & 4.5 & 19.0 & - & 0.016 & -1.0 & 22.5 & - & 0.003 \\
\hline & & Binéfar & 2.3 & 128.9 & 6.8 & 0.001 & -1.1 & 108.8 & 4.8 & 0.003 \\
\hline & & Menàrguens & 1.2 & 76.0 & 4.0 & 0.011 & -1.1 & 83.1 & 3.7 & 0.019 \\
\hline & & Lleida & 0.9 & 208.7 & 11.0 & 0.004 & -1.2 & 271.0 & 12.1 & 0.002 \\
\hline \multirow{4}{*}{ Glyphosate } & \multirow{4}{*}{$600 \mathrm{~g}$ a.i. $\mathrm{ha}^{-1}$} & Susceptible & 3.3 & 105.6 & - & 0.006 & -1.0 & 57.4 & - & 0.029 \\
\hline & & Binéfar & 4.9 & 150.0 & 1.4 & 0.015 & -1.0 & 58.3 & 1.0 & 0.026 \\
\hline & & Menàrguens & 5.6 & 178.8 & 1.7 & 0.017 & -1.7 & 88.6 & 1.5 & 0.005 \\
\hline & & Lleida & 13.6 & 106.5 & 1.0 & 0.014 & -1.0 & 81.2 & 1.4 & 0.005 \\
\hline
\end{tabular}

$\mathrm{LD}_{50}$ and $\mathrm{GR}_{50}$ : herbicide rates required for $50 \%$ of plant mortality or growth reduction, respectively.
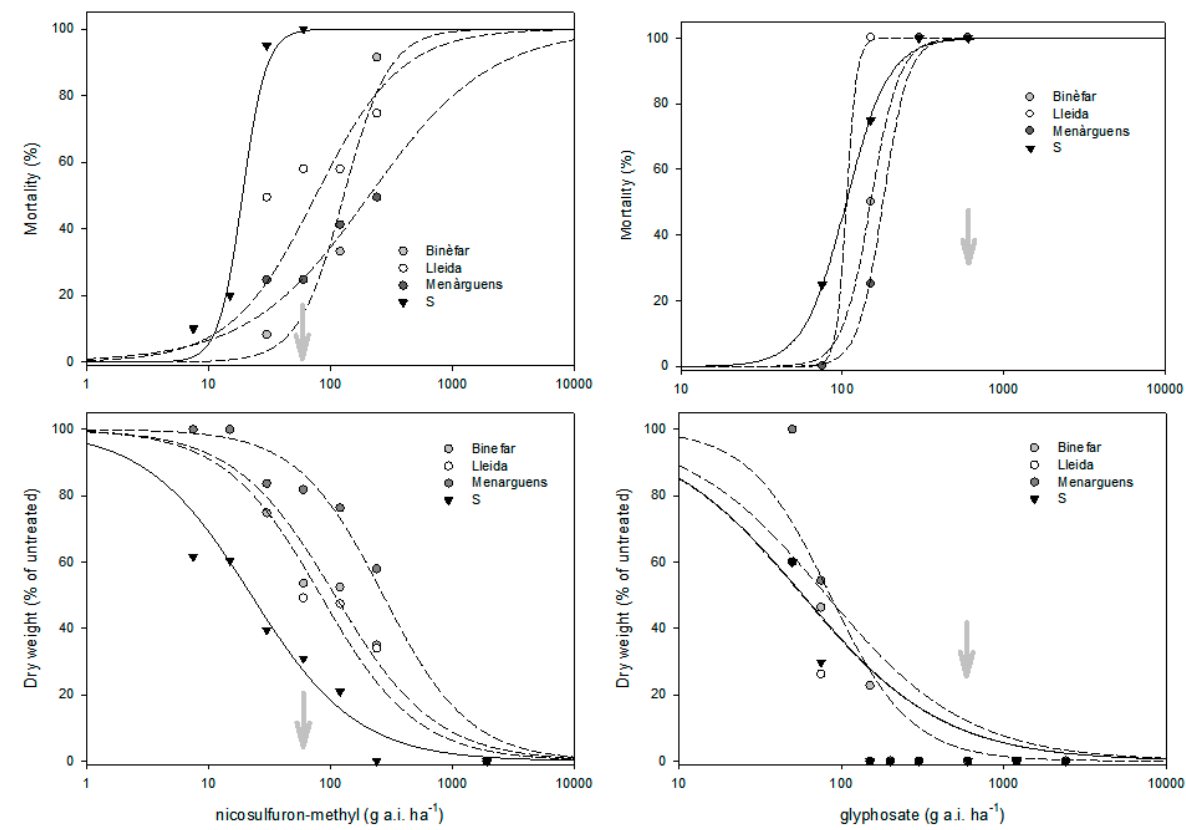

Figure 1. Dose-response regression curves (2018) for mortality (above graphs) and dry weight (below graphs) of S standard (Georgia, US) and Spanish (Binéfar, Menàrguens and Lleida) Amaranthus palmeri populations to nicosulfuron-methyl (left) and glyphosate (right) (log scale). Data for dry weight were expressed as percentage of the mean dry weight of untreated control plants. Grey arrows represent field dose for each herbicide.

For glyphosate, RI were 1.4, 1.7 and 1.0 for Binéfar, Menàrguens and Lleida populations, respectively, in terms of mortality, while considering the percentage of dry weight reduction RI were 1.0, 1.5 and 1.4 (Table 3). LD 50 values ranged from 106 to 179 and from 57 to $89 \mathrm{~g}$ a.i. ha ${ }^{-1}$ for $\mathrm{GR}_{50}$. Finally, no population survived the field recommended dose (Figure 1).

\subsection{Alternative Herbicides}

The effectiveness of all alternative herbicides tested was $100 \%$ of mortality (Table 4 ). At the field recommended rates applied, both treatments in pre-emergence ( $S$-metolachlor and isoxaflutole) or in postemergence (mesotrione, sulcotrione or dicamba), reached full control of the three studied Spanish A. palmeri populations. On the other hand, when ALS-inhibiting herbicides were applied 
in postemergence, both nicosulfuron and thifensulfuron (another sulfonylurea) achieved very poor control, with mortality ranging from $8 \%$ to $56 \%$ and from $25 \%$ to $58 \%$, for each herbicide respectively, depending on the population. Significant differences between populations were only found for ALS-inhibiting herbicides: Lleida population showed the lowest and highest mortality, for thifensulfuron and nicosulfuron, respectively.

Table 4. Mortality (\%) of three Spanish Amaranthus palmeri populations for several herbicides applied either in pre- or postemergence at field recommended rates (1x) in 2014. Herbicide Resistance Action Committee (HRAC) Groups and Sites of Action (SoA) for each herbicide are indicated in the first two columns.

\begin{tabular}{|c|c|c|c|c|c|c|c|}
\hline \multirow[b]{2}{*}{ Herbicide } & \multicolumn{2}{|l|}{ HRAC } & \multirow{2}{*}{$\begin{array}{c}\text { Field Rate } \\
\left(\mathrm{g}_{\text {a.i. }} \mathrm{ha}^{-1}\right)\end{array}$} & \multirow{2}{*}{$\begin{array}{c}\text { Application } \\
\text { Time }\end{array}$} & \multicolumn{3}{|c|}{ Mortality (\%) } \\
\hline & Group & SoA * & & & Binéfar & Menàrguens & Lleida \\
\hline S-metolachlor & K3 & VLCFA & 960 & Pre-emergence & $100 \pm 0$ & $100 \pm 0$ & $100 \pm 0$ \\
\hline Isoxaflutole & $\mathrm{F} 2$ & HPPD & 96 & Pre-emergence & $100 \pm 0$ & $100 \pm 0$ & $100 \pm 0$ \\
\hline Mesotrione & $\mathrm{F} 2$ & HPPD & 150 & Post-emergence & $100 \pm 0$ & $100 \pm 0$ & $100 \pm 0$ \\
\hline Sulcotrione & $\mathrm{F} 2$ & HPPD & 300 & Post-emergence & $100 \pm 0$ & $100 \pm 0$ & $100 \pm 0$ \\
\hline Dicamba & $\mathrm{O}$ & SAH & 288 & Post-emergence & $100 \pm 0$ & $100 \pm 0$ & $100 \pm 0$ \\
\hline Thifensulfuron & B & ALS & 30 & Post-emergence & $32 \pm 12$ & $56 \pm 7$ & $8 \pm 5$ \\
\hline Nicosulfuron & B & ALS & 60 & Post-emergence & $25 \pm 10$ & $25 \pm 10$ & $50 \pm 11$ \\
\hline
\end{tabular}

${ }^{*}$ Inhibit VLCFA (very long chain fatty acids) synthesis or HPPD (4-Hydroxyphenylpyruvate dioxygenase) and ALS (acetolactate synthase) enzymes; SAH for synthetic auxin herbicides.

\subsection{ALS Gene Sequencing}

Substitutions at codons Pro197 of the CAD domain and Trp574 and Ser653 of the BE domain were found in plants of the three analyzed Spanish A. palmeri populations (Table 5). Of the 20 analyzed plants for each population, 9, 11 and 13 individuals for Lleida, Binéfar and Menàrguens populations, respectively, did not have any substitution in codons conferring resistance to ALS-inhibiting herbicides. One amino-acid replacement was identified in position 574 (Tryptophan by Leucine), two different replacements in position 653 (Serine by Asparagine or Isoleucine) and also two different replacements in position 197 (Proline by Threonine or Serine). In Lleida, both heterozygous and homozygous plants for substitution Trp574Leu were found, while only homozygous plants for Ser653Asn were found. No substitution in position 197 was found. 
Table 5. Amino-acid sequence of three Spanish Amaranthus palmeri populations (20 plants for each one) for the ALS gene in BE and CAD domains. Only positions with amino acid change (Trp574, Ser653 and Pro197) and associated with resistance are represented. All sequences were compared with the wild type ALS gene (GenBank: AJ577316). Genotype column presents if plants were resistant (R) heterozygous (RS) or R homozygous (RR) for each position.

\begin{tabular}{|c|c|c|c|c|c|c|}
\hline \multicolumn{4}{|l|}{ ALS } & \multicolumn{3}{|c|}{ Population (Number of Plants) } \\
\hline Domain & Position & Amino Acid & Genotype & Lleida & Binéfar & Menàrguens \\
\hline \multirow[t]{6}{*}{$\mathrm{BE}$} & Trp574 & Leu & RS & 5 & 1 & 1 \\
\hline & & & $\mathrm{RR}$ & 3 & 0 & 0 \\
\hline & Ser653 & Asn & $\mathrm{RS}$ & 0 & 0 & 0 \\
\hline & & & RR & 3 & 0 & 0 \\
\hline & & Ile & $\mathrm{RS}$ & 0 & 0 & 0 \\
\hline & & & $\mathrm{RR}$ & 0 & 0 & 1 \\
\hline \multirow[t]{6}{*}{ CAD } & Pro197 & Thr & RS & 0 & 2 & 4 \\
\hline & & & $\mathrm{RR}$ & 0 & 6 & 0 \\
\hline & & Ser & RS & 0 & 0 & 0 \\
\hline & & & $\mathrm{RR}$ & 0 & 0 & 1 \\
\hline & & \multicolumn{2}{|c|}{ Susceptible * } & 9 & 11 & 13 \\
\hline & & \multicolumn{2}{|c|}{ Resistant } & 11 & 9 & 7 \\
\hline
\end{tabular}

* Plants were ascribed as resistant or susceptible only according the presence of amino substitutions in the ALS gene.

In Binéfar, one heterozygous plant for Trp574Leu was found, while several heterozygous and homozygous plants for Pro197Thr were identified. No plants with changes in position 653 were found. For Menàrguens, amino acid substitutions were found in the three codons: one heterozygous plant for Trp574Leu, one homozygous plant for Ser653Ile, four heterozygous plants for Pro197Ther and one homozygous plant for Pro197Ser. Finally, it is important to notice that one plant sampled in Lleida harbored the substitutions Trp574Leu and Ser653Asn in the BE domain, while one plant from Menàrguens, had the amino acid substitutions Ser653Ileu and Pro197Thr of the BE and CAD domains, respectively. The configuration (cis or trans) of double mutations was not determined.

\subsection{ISSR DNA Fingerprint}

The total number of polymorphic markers obtained with the seven ISSR primers used was 256. As observed in Figure 2, all the plants studied shared a genetic relationship of 0.67 , showing a genetic variation of $33 \%$ between all the individuals analyzed. Two big distinct clusters were observed at a similarity level of 0.62 . The first cluster contained most of the plants belonging to localities of Lleida and Menàrguens, while in the second cluster all individuals sampled in Binéfar were found (Group 3, Figure 2), excepting two found in Group 2 (Figure 2). In the first cluster, at a coefficient level of 0.72 , two groups were identified, one with plants sampled in Lleida, Group 1 (Figure 2), (excepting two from Menàrguens), the other one, Group 2 (Figure 2), with individuals from Menàrguens, excepting one from Binéfar. 


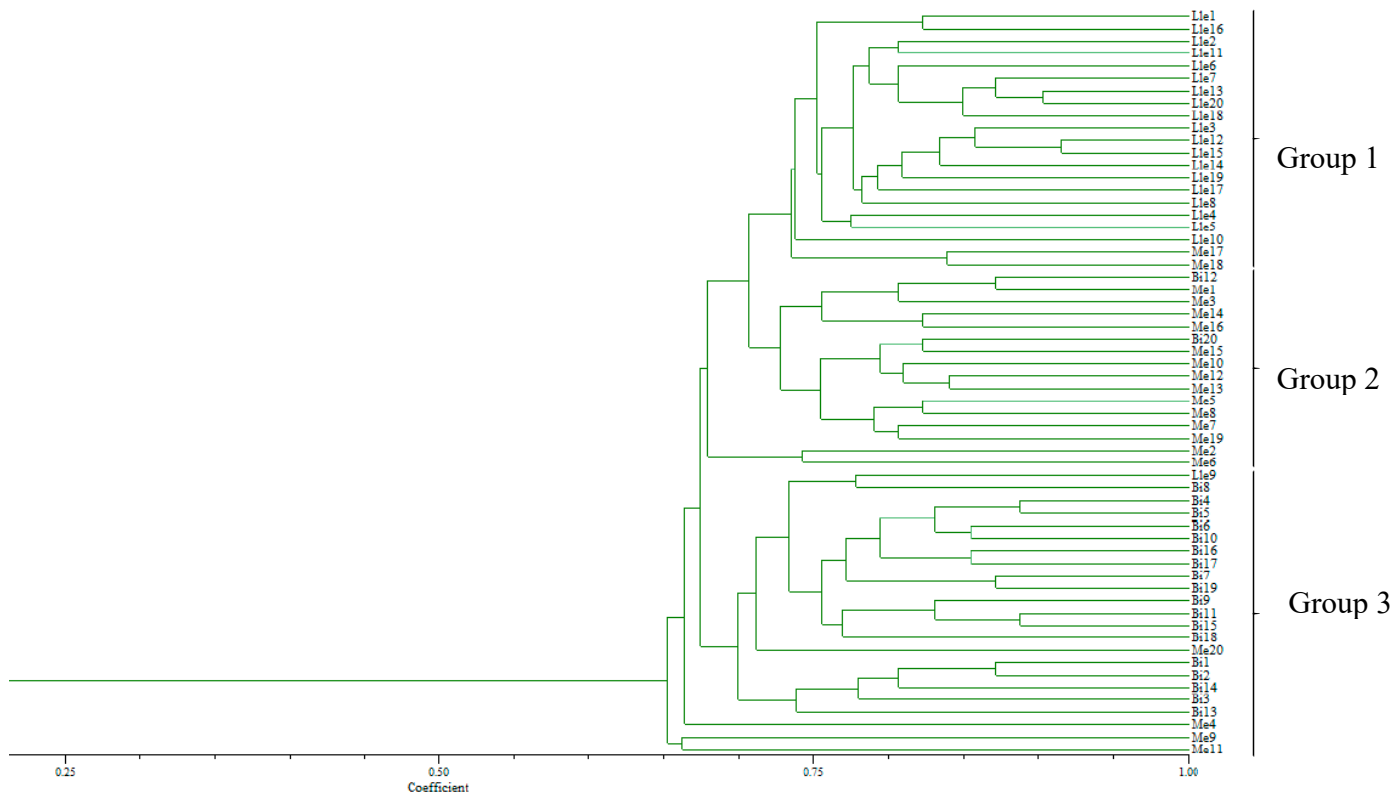

Figure 2. Unweighted pair group method with arithmetic mean (UPGMA) dendrogram using distance of Nei [27] showing the molecular relationships using seven inter simple sequence repeat (ISSR) between 60 plants from three Spanish Amaranthus palmeri populations. Lle1-Lle20: plants from Lleida; Me1-Me20: plants from Menàrguens; Bi1-Bi20: plants from Binéfar.

Finally, there were three plants that were not found among the previously described groups (Figure 2, bottom part). All of them were sampled in the locality of Menàrguens.

\section{Discussion}

Dose-response trials in the greenhouse confirmed that all three A. palmeri populations established in northeastern Spain were $S$ to glyphosate but R to ALS-inhibiting herbicides. For the EPSPS inhibitor glyphosate, $\mathrm{GR}_{50}$ values estimated in this research were within the range (i.e., 66 to $194 \mathrm{~g}$ a.i. $\mathrm{ha}^{-1}$ ) of other A. palmeri $\mathrm{S}$ populations reported in the literature $[29,30]$. In addition, $\mathrm{LD}_{50}$ values around $100 \mathrm{~g}$ a.i. ha ${ }^{-1}$ estimated in previous studies for glyphosate $S$ populations [31] were in accordance with those found here.

Concerning the ALS inhibitor nicosulfuron, in terms of mortality, $\mathrm{LD}_{50}$ for the $\mathrm{S}$ population $\left(19 \mathrm{~g}\right.$ a.i. $\left.\mathrm{ha}^{-1}\right)$ was in the range of other studies $\left(<18 \mathrm{~g}\right.$ a.i. $\left.\mathrm{ha}^{-1}\right)$ [32]. Accordingly, $\mathrm{GR}_{50}$ values to nicosulfuron (percent of fresh weight reduction) of $18 \mathrm{~g}$ a.i. $\mathrm{ha}^{-1}$ were reported in $\mathrm{S}$ populations from Argentine [32], similar to those found in this study $\left(22 \mathrm{~g}\right.$ a.i. ha $\left.{ }^{-1}\right)$. For the $\mathrm{R}$ populations, the $\mathrm{GR}_{50}$ values obtained here ( 83 to $271 \mathrm{~g}$ a.i. ha ${ }^{-1}$ ) were also in the range of other A. palmeri populations $\mathrm{R}$ to nicosulfuron, though usually they can be higher $\left(>350 \mathrm{~g}\right.$ a.i. ha $\left.{ }^{-1}\right)$ [32]. In addition, RI above 20 are usually estimated in other $A$. palmeri populations $\mathrm{R}$ to different ALS-inhibiting herbicides, both based on $\mathrm{LD}_{50}$ or $\mathrm{GR}_{50}$ [22]. Relative low resistance levels to nicosulfuron found in these three A. palmeri populations established in Spain could be explained by the relative high frequency of $S$ plants found (around $50 \%$ ) based on the sequencing of the ALS gene (Table 5).

The molecular analyses of $A L S$ gene sequence revealed target site mutations in the three A. palmeri populations that confer resistance to ALS inhibitors, corroborating the results from the dose-response experiments. Amino acid changes were found in positions Pro197, Trp574 and Ser653, already described in this species [20]. On the other hand, the specific amino acid substitutions Pro197Thr and Ser653Ile, found in plants from Binéfar and Menàrguens and in one homozygous plant from Menàrguens, respectively, are - to our knowledge - the first report worldwide for A. palmeri. To date, the Ser653Ile substitution has been found only in Setaria viridis [20]. Changes in positions Pro197 and Trp574 are expected to persist in these populations, since mutations at these points do not represent a major 
fitness cost [33]. The latter, in fact, was the only position changed in all the three populations, potentially conferring cross-resistance to all ALS chemistries [33]. Finally, it might be important to highlight that the percent mortalities observed matched the percent of plants genotyped as R. Of the plants analyzed, $55 \%, 45 \%$ and $35 \%$ had amino acid substitutions in the ALS gene for Lleida, Binéfar and Menárguens populations, respectively (Table 5). These percentages roughly correlated with estimated mortalities at field rate (Figure 1, Table 4). This would rule out the presence of non-target site resistance to ALS inhibitors, but it should be further confirmed.

All three A. palmeri populations established in northeastern Spain and R to ALS-inhibiting herbicides, were fully controlled with other herbicides at field rates from three different modes of action (Table 4). Therefore, there is still the chance for managing the population in Menàrguens that has already infested a maize field. On the other hand, it is important to notice that this species is able to develop resistance to all tested sites of action herein [20], so an adequate integrated weed management should be required. Among chemical strategies, rotating sites of action (SoA), herbicide mixtures with different (SoA) and sequential applications should be considered [34]. Amon non-chemical and curative strategies, scouting for further resistance, cultural techniques such as seeding dates/crop rotations, tillage/hand weeding, edge management control and plantings to reduce invasion potential should be implemented [34]. Finally, cross-resistance to the sulfonylurea thifensulfuron was observed at field rate, as expected by the point mutations detected in these populations [33].

Gene flow, diversity analyses, tracking herbicide $\mathrm{R}$ biotypes, population structure and genetic mapping is feasible for invasive weeds using ISSRs markers [35]. Three groups of A. palmeri plants were distinguishable according the UPGMA analyses, and most sampled plants in each locality were properly classified in each group (Figure 2). The three A. palmeri populations (groups) had a genetic divergence of $33 \%$, while between Lleida and Menàrguens divergence it was slightly lower (28\%). This genetic differences among populations suggest that plants from these three localities are not closely related $[36,37]$ and might come from different colonization events. Accordingly, the occurrence of different and multiple amino acid substitutions among $\mathrm{R}$ plants of the three A. palmeri populations suggests a complex and different evolutionary history of these resistance traits. While not definitive, the absence of mutations in position Pro197 in the Lleida population (present in the other two) or also the absence in position Ser653 in the Binéfar population, indicates potential different arrivals to the country and from different sources. For example, the absence of mutations in Ser653 in A. palmeri from Argentina and the presence of both Trp574 and Ser653 in plants from Brazil, suggested that independent introductions of the species occurred in the two countries [38]. Moreover, changes in different positions in the ALS gene also suggest different herbicide selection pressures and cropping systems. The selection of ALS alleles conferring more imidazolinone-specific herbicide resistance, such as Ser653, point out to soybean as the predominant crop and imazethapyr treatments, while changes in position Pro197 to the use of sulfonylureas in maize, as suggested for A. tuberculatus [39]. Therefore, the hypothesis that not only of different introduction events but also different sources is reinforced for these three A. palmeri populations established in NE Spain. Finally, it has to be stressed that there were nine years between the likely introduction of these populations and sample collection. Therefore, it cannot be ruled out that populations from the same source may have diverged through new mutation events.

As proven in this research, all populations were glyphosate $S$, so the introduction events might have occurred before glyphosate resistance started to evolve in this species in North America. The main selecting agent for the resistance to this herbicide in A. palmeri were glyphosate $\mathrm{R}$ crops and the first reported case was in 2006 [40]. Hence, the arrival of A. palmeri to Spain might be already quite old and might have occurred before 2006.

This research reports for the first time the presence of herbicide resistance biotypes of A. palmeri, not only in Spain, but also in Europe. The occurrence of herbicide R A. palmeri is very threatening to the sustainability of both irrigated arable crops and natural ecosystems. The species is starting to enter some maize fields and, in this sense, the Servei de Sanitat Vegetal from the Department of Agricultura, Ramaderia, Pesca i Alimentació of the Generalitat de Catalunya and also the Servicio de Sanidad Vegetal 
of the Gobierno de Aragon, are already undertaking the corresponding legislative measures to contain and eradicate these populations. Recently, an Order at the Regional Catalan level (DOGC number 7959, 13th September 2019) was issued [41] declaring the presence of A. palmeri and stating that it is of public interest to establish the required measures to control it [42]. Unfortunately, based on our own monitoring efforts, we have found new A. palmeri populations around the studied area (no more available data). Thus, this aggressive species is spreading, maybe through harvesting machinery and irrigation channels. Hence, it is urgent to undertake a pest risk assessment to develop appropriate management and eradication strategies in accordance with particular characteristics of Spanish and European ecological and agricultural systems. Moreover, in the Region of Extremadura ( $800 \mathrm{~km}$ away), the species has already been detected (Dr. Osuna, personal communication). Preliminary studies have confirmed the presence of the amino acid substitution Trp574Leu in this region (personal communication). Finally, ALS R A. palmeri plants have already arrived to Italy too (Dr. Donato Loddo, personal communication). Therefore, it is clear that several introduction and dispersal processes across Europe are occurring, probably through contaminated grain from America and will continue if preventive measures are not quickly implemented. The prevention of further introductions is warranted, since this species is able to evolve resistance to a wide range of sites of action and glyphosate resistance is already spread across America [20]. Hence, new arrivals with new herbicide $\mathrm{R}$ traits would make its management even more difficult and probably require more aggressive and expensive control measures.

Author Contributions: Conceptualization, J.T., M.D.O. and J.R.; methodology, J.T., A.R.-E., Y.R., M.D.O., R.G.L. and J.R.; software, J.T., A.R.-E., Y.R., M.D.O., R.G.L. and J.R.; validation, J.T., A.R.-E., Y.R., M.D.O., R.G.L. and J.R.; formal analysis, J.T., A.R.-E., Y.R., M.D.O., R.G.L. and J.R.; investigation, J.T., A.R.-E., Y.R., M.D.O., R.G.L. and J.R.; resources, J.T., M.D.O. and J.R.; data curation, J.T., A.R.-E., Y.R., M.D.O., R.G.L. and J.R.; writing-original draft preparation, J.T., A.R.-E. and J.R.; writing-review and editing, J.T., A.R.-E., Y.R., M.D.O., R.G.L. and J.R.; visualization, J.T., A.R.-E., Y.R., M.D.O., R.G.L. and J.R.; supervision, J.T., M.D.O. and J.R.; project administration, J.R.; funding acquisition, J.T. and J.R. All authors have read and agreed to the published version of the manuscript.

Funding: This work was funded by Spanish Government through the project AGL2017-83325-C4-2-R (AEI/FEDER/UE). Joel Torra acknowledges support from the Spanish Ministry of Science, Innovation and Universities (grant Ramon y Cajal RYC2018-023866-I).

Acknowledgments: We would like to acknowledge Maria Casamitjana for her help in collecting seeds and greenhouse trials.

Conflicts of Interest: The authors declare no conflicts of interest. The funders had no role in the design of the study; in the collection, analyses or interpretation of data; in the writing of the manuscript or in the decision to publish the results.

\section{References}

1. Paini, D.R.; Sheppard, A.W.; Cook, D.C.; De Barro, P.J.; Worner, S.P.; Thomas, M.B. Global threat to agriculture from invasive species. Proc. Natl. Acad. Sci. USA 2016, 113, 7575-7579. [CrossRef] [PubMed]

2. Pimentel, D.; Zuniga, R.; Morrison, D. Update on the environmental and economic costs associated with alien-invasive species in the United States. Ecol. Econ. 2005, 52, 273-288. [CrossRef]

3. Boscutti, F.; Sigura, M.; De Simone, S.; Marini, L. Exotic plant invasion in agricultural landscapes: A matter of dispersal mode and disturbance intensity. Appl. Veg. Sci. 2018, 21, 250-257. [CrossRef]

4. Lyons, K.; Prather, T. Invasive Plant Ecology in Natural and Agricultural Systems. Invasive Plant Sci. Manag. 2013, 6, 457. [CrossRef]

5. Ehleringer, J. Ecophysiology of Amaranthus palmeri, a Sonoran Desert summer annual. Oecologia 1983, 57, 107-112. [CrossRef] [PubMed]

6. Chaudhari, S.; Jordan, D.; York, A.; Jennings, K.M.; Cahoon, C.W.; Chandi, A.; Inman, M.D. Biology and management of glyphosate-resistant and glyphosate-susceptible Palmer amaranth (Amaranthus palmeri) phenotypes from a segregating population. Weed Sci. 2017, 65, 755-768. [CrossRef]

7. Keeley, P.E.; Carter, C.H.; Thullen, R.J. Influence of planting date on growth of Palmer amaranth (Amaranthus palmeri). Weed Sci. 1987, 35, 199-204. [CrossRef] 
8. Smith, K.L.; Doherty, R.C.; Bullington, J.A.; Meier, J.R.; Bagavathiannan, M.V. Seed production potential of Palmer amaranth in Arkansas. In Summaries of Arkansas Cotton Research 2011; Oosterhuis, D.E., Ed.; University of Arkansas Division of Agriculture AAES Research Series 602: Little Rock, AR, USA, 2011; pp. 40-43.

9. Sosnoskie, L.; Webster, T.; Culpepper, A. Glyphosate resistance does not affect Palmer amaranth (Amaranthus palmeri) seedbank longevity. Weed Sci. 2013, 61, 283-288. [CrossRef]

10. Ward, S.; Webster, T.; Steckel, L. Palmer amaranth (Amaranthus palmeri): A review. Weed Technol. 2013, 27, 12-27. [CrossRef]

11. EPPO [European and Mediterranean Plant Protection Organization] (2020) EPPO Alert List. Available online: http://www.eppo.int/INVASIVE_PLANTS/ias_lists.htm\#AlertList (accessed on 8 January 2020).

12. Carretero, J.L. Amaranthus. In Flora Iberica Vol II: Platanaceae-Plumbaginaceae (Partim); Castroviejo, S., Ed.; Real Jardín Botánico CSIC: Madrid, Spain, 1990; pp. 559-569.

13. Sánchez-Guillón, E.; Verloove, F. New records of interesting xenophytes in Spain. II. Lagascalia 2009, 29, 281-291.

14. Verloove, F.; Sánchez-Guillón, E. New records of interesting xenophytes in the Iberian Peninsula. Acta Bot. Malac. 2008, 33, 147-167. [CrossRef]

15. Recasens, J.; Conesa, J.A. Presencia de la mala hierba Amaranthus palmeri en el NE de la península Ibérica. Una amenaza como potencial invasora de cultivos extensivos de regadío. Boletín De Sanid. Veg. Plagas 2011, 37, 129-132.

16. Recasens, J.; Osuna, M.D.; Royo-Esnal, A.; Torra, J. Amaranthus palmeri S. Watson en Cataluña y Aragón. Tres poblaciones con un mismo origen? In Proceedings of the XVI Congreso de la Sociedad Española de Malherbología, Pamplona, Spain, 25-27 October 2017; pp. 15-20.

17. Palma-Bautista, C.; Torra, J.; García, M.J.; Bracamonte, E.R.; Rojano-Delgado, A.M.; Alcántara-de la Cruz, R.; De Prado, R. Reduced absorption and impaired translocation endows glyphosate resistance in Amaranthus palmeri harvested in glyphosate-resistant soybean from Argentina. J. Agric. Food Chem. 2019, 67, 1052-1060. [CrossRef] [PubMed]

18. Gaines, T.A.; Zhang, W.; Wang, D.; Bukun, B.; Chisholm, S.T.; Shaner, D.; Nissen, S.J.; Patzoldt, W.L.; Tranel, P.; Culpepper, A.S.; et al. Gene amplification confers glyphosate resistance in Amaranthus palmeri. Proc. Natl. Acad. Sci. USA 2009, 107, 1029-1034. [CrossRef] [PubMed]

19. Domínguez-Valenzuela, J.A.; Gherekhloo, J.; Fernández-Moreno, P.T.; Cruz-Hipolito, H.E.; La Cruz, R.A.-D.; Sánchez-González, E.; De Prado, R. First confirmation and characterization of target and non-target site resistance to glyphosate in Palmer amaranth (Amaranthus palmeri) from Mexico. Plant Physiol. Biochem. 2017, 115, 212-218. [CrossRef] [PubMed]

20. Heap, I. International Survey of Herbicide Resistant Weeds. Available online: http://www.weedscience.org (accessed on 15 January 2020).

21. Horak, M.J.; Peterson, D.E. Biotypes of Palmer amaranth (Amaranthus palmeri) and common waterhemp (Amaranthus rudis) are resistant to imazethapyr and thifensulfuron. Weed Technol. 1995, 9, 192-195. [CrossRef]

22. Larran, A.S.; Palmieri, V.E.; Perotti, V.E.; Lieber, L.; Tuesca, D.; Permingeat, H.R. Target-site resistance to acetolactate synthase (ALS)-inhibiting herbicides in Amaranthus palmeri from Argentina. Pest Manag. Sci. 2017, 73, 2578-2584. [CrossRef]

23. Tranel, P.J.; Wright, T.R.; Heap, I.M. Mutations in Herbicide-Resistant Weeds to ALS Inhibitors. Available online: http://www.weedscience.com (accessed on 15 January 2020).

24. Varanasi, V.; Brabham, C.; Korres, N.; Norsworthy, J. Nontarget site resistance in Palmer amaranth [Amaranthus palmeri (S.) Wats.] confers cross-resistance to protoporphyrinogen oxidase-inhibiting herbicides. Weed Technol. 2019, 33, 349-354. [CrossRef]

25. Bravo, W.; Leon, R.G.; Ferrell, J.A.; Mulvaney, M.J.; Wood, C.W. Differentiation of life-history traits among Palmer amaranth populations (Amaranthus palmeri) and its relation to cropping systems and glyphosate sensitivity. Weed Sci. 2017, 65, 339-349. [CrossRef]

26. Prado, M.D.; De Prado, R.; Franco, A.R. Design and optimization of degenerated universal primers for the cloning of the plant acetolactate synthase conserved domains. Weed Sci. 2004, 52, 487-491. [CrossRef]

27. Nei, M. Genetic distance between populations. Am. Nat. 1972, 106, 283-292. [CrossRef]

28. Rohlf, F.J. NTSYS-Numerical Taxonomy and Multivariate Analysis System; Exeter Publishing Setauket: New York, NY, USA, 1998. 
29. Kumar, V.; Liu, R.; Boyer, G.; Stahlman, P.W. Confirmation of 2,4-D resistance and identification of multiple resistance in a Kansas Palmer amaranth (Amaranthus palmeri) population. Pest Manag. Sci. 2019, 75, 2925-2933. [CrossRef] [PubMed]

30. Mohseni-Moghadam, M.; Schroeder, J.; Heerema, R.; Ashigh, J. Resistance to glyphosate in Palmer amaranth (Amaranthus palmeri) populations from New Mexico pecan orchards. Weed Technol. 2013, 27, 85-91. [CrossRef]

31. Kaundun, S.S.; Jackson, L.V.; Hutchings, S.-J.; Galloway, J.; Marchegiani, E.; Howell, A.; Carlin, R.; Mcindoe, E.; Tuesca, D.; Moreno, R. Evolution of Target-Site Resistance to Glyphosate in an Amaranthus palmeri Population from Argentina and Its Expression at Different Plant Growth Temperatures. Plants 2019, 8, 512. [CrossRef] [PubMed]

32. Berger, S.; Madeira, P.; Ferrell, J.; Gettys, L.; Morichetti, S.; Cantero, J.; Nuñez, C. Palmer amaranth (Amaranthus palmeri) identification and documentation of ALS-resistance in Argentina. Weed Sci. 2016, 64, 312-320. [CrossRef]

33. Yu, Q.; Powles, S.B. Resistance to AHAS inhibitor herbicides: Current understanding. Pest Manag. Sci. 2014, 70, 1340-1350. [CrossRef]

34. Norsworthy, J.K.; Ward, S.M.; Shaw, D.R.; Llewellyn, R.S.; Nichols, R.L.; Webster, T.M.; Bradley, K.W.; Frisvold, G.; Powles, S.B.; Burgos, N.R.; et al. Reducing the risks of herbicide resistance: Best management practices and recommendations. Weed Sci. 2012, 60, 31-62. [CrossRef]

35. Slotta, T.A.B. What we know about weeds: Insights from genetic markers. Weed Sci. 2008, 56, 322-326. [CrossRef]

36. Dinelli, G.; Bonetti, A.; Marotti, I.; Minelli, M.; Catizone, P. Characterization of Italian populations of Lolium spp. resistant and susceptible to diclofop by inter simple sequence repeat. Weed Sci. 2004, 52, 554-563. [CrossRef]

37. Mengistu, L.A.W.; Messersmith, C.G.; Christoffers, M.J. Genetic diversity of herbicide-resistant and -susceptible Avena fatua populations in North Dakota and Minnesota. Weed Res. 2005, 45, 413-423. [CrossRef]

38. Küpper, A.; Borgato, E.; Patterson, E.; Gonçalves Netto, A.; Nicolai, M.; de Carvalho, S.J.P.; Nissen, S.J.; Gaines, T.A.; Christoffoleti, P.J. Multiple resistance to glyphosate and acetolactate synthase inhibitors in Palmer amaranth (Amaranthus palmeri) identified in Brazil. Weed Sci. 2017, 65, 317-326. [CrossRef]

39. Patzoldt, W.; Tranel, P. Multiple ALS mutations confer herbicide resistance in waterhemp (Amaranthus tuberculatus). Weed Sci. 2007, 55, 421-428. [CrossRef]

40. Culpepper, A.S.; Grey, T.L.; Vencill, W.K.; Kichler, J.M.; Webster, T.M.; Brown, S.M.; York, A.C.; Davis, J.W.; Hanna, W.W. Glyphosate-resistant Palmer amaranth (Amaranthus palmeri) confirmed in Georgia. Weed Sci. 2006, 54, 620-626. [CrossRef]

41. DOGC. Ordre ARP/172/2019, de 10 de setembre, per la qual es declara l'existència de la mala herba Amaranthus palmeri i es qualifica d'utilitat pública la lluita contra aquesta; Diari Oficial de la Generalitat de Catalunya núm. 7959; Entitat Autònoma del Diari Oficial i de Publicacions (EADOP): Barcelona, Spain, 13 September 2019.

42. Recasens, J.; Conesa, J.A.; Juárez-Escario, A. Las invasiones vegetales en sistemas agrícolas. Retrospectiva de los últimos 40 años en Cataluña. Inf. Tec. Econ. Agrar. 2019. [CrossRef]

(C) 2020 by the authors. Licensee MDPI, Basel, Switzerland. This article is an open access article distributed under the terms and conditions of the Creative Commons Attribution (CC BY) license (http://creativecommons.org/licenses/by/4.0/). 